\title{
The International Integrated Reporting Framework: Key Issues and Future
}

\section{Research Opportunities}

\author{
Mandy Cheng* \\ Wendy Green* \\ Pieter Conradie $^{* *}$ \\ Noriyuki Konishi**** \\ Andrea Romi****
}

* m.cheng@unsw.edu.au and w.green@unsw.edu.au

Associate Professors of Accounting,

School of Accounting, Australian School of Business,

University of New South Wales, Australia 2052

** pieter.conradie@up.ac.za

Program Director: Integrated Reporting

The Albert Luthuli Centre for Responsible Leadership

Faculty of Economic and Management Sciences

University of Pretoria, Hatfield South Africa

*** hanko.konishi@nifty.com

Professor of Accounting

Graduate School of Professional Accountancy

Aoyama Gakuin University

Shibuya-Ku, Tokyo Japan

****andrea.romi@ttu.edu

Assistant Professor of Accounting

Rawls College of Business

Texas Tech University

Lubbock Texas USA

Keywords: Integrated Reporting, capitals, future research questions 


\begin{abstract}
This paper has three main aims. First, the paper introduces the concept of Integrated Reporting $(<\mathrm{IR}>$ ) as described by the International Integrated Reporting Council (IIRC). A background to the development of the $<\mathrm{IR}>$ concept over the four year period from the inception of the IIRC in 2010 is provided, culminating in the release by the IIRC of a Consultation Draft (CD) of the $<$ IR $>$ Framework in March 2013. Second, the paper discusses key issues currently being debated relating to the $\mathrm{CD}$ that the IIRC will need to resolve prior to expected release of their $<\mathrm{IR}>$ Framework in late 2013. This discussion is based on issues identified and reported to the IIRC by a sub-committee of the International Association for Accounting Education and Research (IAAER) comprised of international accounting academics. Finally, the paper identifies a range of potential research issues relating to the development and implementation of $<\mathrm{IR}>$.
\end{abstract}

\title{
1. BACKGROUND
}

There have been increasing concerns that traditional corporate reporting is insufficient to meet the information needs of a variety of stakeholders (Adams et al. 2011; FRC 2009, 2011; Cohen et al. 2012). In response to such concerns, many companies have attempted to improve the information available for stakeholder decisions through supplementing their traditional financial reporting with the reporting of non-financial information (KPMG 2011; Cohen et al. 2012). This non-financial information is typically reported via a range of mechanisms including stand-alone sustainability reports, corporate social responsibility (CSR) reports or within the annual report (Simnett et al. 2009: KPMG 2011; Cohen et al. 2012). While this additional information has been shown to be value-relevant (Clarkson et al. 2004; Dhaliwal et al. 2011, 2012) the extent of reported nonfinancial information included in such reports is often overwhelming in quantity, with sustainability reports reaching up to 200 pages in length (KPMG and FERF 2011). Further, the financial and nonfinancial reports are not provided in a manner which facilitates stakeholder understanding of the company. For example, only seven S\&P 500 companies integrated their financial and non-financial 
information despite 499 providing some sustainability disclosures (Investor Responsibility Research Centre Institute (IRRCI) 2013). As such, the usefulness of the provided information is often diminished (KPMG and FERF 2011).

In 2010, the newly formed International Integrated Reporting Council (IIRC) proposed that the solution to this problem would be for companies to provide a clear link between the reported nonfinancial information and the financial information in a manner allowing an assessment of the ongoing future performance of the company. The mechanism the IIRC proposed to achieve this was for companies to produce a separate report (i.e. an Integrated Report) that integrates the companies' financial and non-financial information. Specifically, the IIRC recommended a process of $<$ IR $>$ whereby an organisations' value creation over time would be reported in a concise report, called an integrated report, which would communicate an organization's strategy, governance, performance and prospects, in the context of its external environment, in order to show value creation over the short, medium and long term (IIRC 2013).

This paper has three specific aims which are addressed in each of the three ensuing sections. The first aim is to provide an introduction to the concept of $<\mathrm{IR}>$. The second aim is to discuss the key issues currently being debated relating to the $\mathrm{CD}$ that the IIRC will need to resolve prior to expected release of their $<\mathrm{IR}>$ Framework in late 2013. The final aim is to identify a range of potential research issues relating to the development and implementation of $<\mathrm{IR}>$.

\section{INTRODUCTION TO INTEGRATED REPORTING}

The International Integrated Reporting Council (IIRC) is a "global coalition of regulators, investors, companies, standard setters, the accounting profession and NGOs" and brings together "the relevant and informed people and organisations" (IIRC 2013a) involved in corporate reporting, with the aim of preparing a conceptual framework for the preparation of a concise, user-oriented corporate report entitled an "Integrated Report". The groups represented in the IIRC include: regulators and standard 
setters (including the International Organization of Securities Commissions (IOSCO), the International Accounting Standards Board (IASB), and the American Institute of Certified Public Accountants); the current Chairs of the Big 4 accounting firms and other global audit firm networks; leading international groups with broad sustainability mandates (including the Global Reporting Initiative (GRI), and the Carbon Standards Disclosure Board (CDSB)); international bodies (including The World Bank, the United Nations Global Compact, World Business Council for Sustainable Development (WBCSD), and Principles for Responsible Investment (PRI)); international accounting and auditing bodies (including the International Federation of Accountants (IFAC) and the Institute of Internal Auditors (IIA)); investor groups; representatives from leading corporate reporters; and leading academics in corporate and extended reporting (IIRC 2013a).

The aim of an Integrated Report is to allow a better communication of the company's short, medium and longer term value creation propositions through providing "a concise communication about how a company's strategy, governance, performance and prospects, in the context of its external environment, lead to the creation of value over the short, medium and long term" (IIRC 2013b, 8).

At the heart of the $<\mathrm{IR}>$ conceptual framework is the notion that companies should expand their reporting to include all of the resources they use as inputs to their business activities. The IIRC uses the term capitals to denote these various resources, with six capitals being identified: Financial; Manufactured; Intellectual; Human; Social and relationship; and Natural (IIRC 2013b). In addition, the framework requires that a description of the company's business model be included, with particular emphasis on how this business model and the underlying strategies integrate with the six capitals. A further point of differentiation from traditional financial statements is that $<\mathrm{IR}>$ does not simply reflect past transactions and events, but rather responds to demands for more forward looking information (Holder-Webb et al 2008, 2009) through considering short, medium and long term time frames. In this way, with key opportunities and risks being identified and reported, 
stakeholders would be provided with valuable information regarding the ability of the company to survive in the future.

Over the past four years the IIRC has made significant progress in developing a framework for $<$ IR $>$. In particular, in September 2011 the IIRC released a Discussion Paper, "Towards Integrated Reporting - Communicating Value in the 21st Century" (IIRC 2011) in order to receive feedback on their $<\mathrm{IR}>$ concept. This Discussion Paper was open for public comment for three months from September 2011. After due consideration of submissions from stakeholders on the 2011 discussion paper the IIRC released their Consultation Draft of the International $<\mathrm{IR}>$ Framework Integrated Reporting (CD) in April 2013 (IIRC 2013b). The issues discussed in section three of this paper are derived from the submission to the IIRC on their CD provided by a sub-committee of the IAAER comprising international accounting academics. The due process of consideration of all stakeholder comments is expected to culminate in the release of the International $<\mathrm{IR}>$ Framework in December 2013 (IIRC 2013a).

A number of countries have already embraced $<\mathrm{IR}>$. Notably, South Africa was the first country to require listed companies to produce an integrated report. Specifically, following on from the King III initiatives in March 2010, listed companies on the Johannesburg Stock Exchange were mandated (on a comply or explain basis) to provide an Integrated Report. In order to improve the integrativeness of current disclosures, the Integrated Reporting Committee of South Africa (IRCSA) was established in 2011. A recent report by Ernst \& Young (2012) notes that a number of stock exchanges throughout the world, including Sao Paulo, Singapore, Kuala Lumpur and Copenhagen, have implemented a report or explain requirement relating to the reporting of environmental, social and governance issues. Significant progress toward $<\mathrm{IR}>$ has also been made by France through the passing of the Grenelle II Act in 2012. This Act requires the reporting of environmental and social issues by all companies as well as their independent third party verification. In addition, in April 
2013, the European Commission announced proposals to amend the Fourth and Seventh Accounting Directives, to encourage greater disclosure of non-financial information by large European companies (IIRC 2013c).

Apart from mandated disclosures, a group of over 100 organisations, termed the IIRC Business Network, across more than 20 countries, have voluntarily engaged in the IIRC $<$ IR $>$ Pilot Program in order to test the principles and concepts of $<\mathrm{IR}>$ in their organizations (IIRC 2013a). These companies include The Coca Cola Company, Danone, Deutsche Bank, HSBC Holding, Marks and Spencer, Microsoft Corporation, Prudential Financial, Tata Steel, and Unilever. In addition, over 30 institutional investor networks are also providing their input to ensure the investor's perspectives are appropriately reflected in the framework's development (IIRC 2013a). Inciteful comments provided by the pilot companies relating to the implementation of $<\mathrm{IR}>$ have been published by the IIRC as a pilot companies program 2012 yearbook (IIRC 2012b).

\section{Consultation Draft of the International $<$ IR $>$ Framework Integrated Reporting (CD)}

The $\mathrm{CD}$ is a principles-based document containing three main sets of requirements for the preparation of an Integrated Report meeting the aims outlined in the previous section. The first requirements are called fundamental concepts, the second are guiding principles and the third are content elements (IIRC2013b).

\section{Fundamental Concepts}

The $\mathrm{CD}$ notes that the fundamental concepts of $<\mathrm{IR}>$ underpin and reinforce the principles-based requirements set out in the guiding principles and content elements. These fundamental concepts centre on:

- the various capitals that a company uses and affects,

- the company's business model and 
- the creation of value over time (IIRC 2013b, 6).

\section{Capitals}

In the $<\mathrm{IR}>$ Framework, the capitals are the stores of value (or relationships) that are input into a company's business model. Through the activities and outputs of the company these capitals are enhanced, consumed, modified, destroyed or otherwise affected (IIRC 2013b, 11). The framework identifies the following six capitals that companies should include in their reporting:

- financial (i.e. the pool of funds),

- manufactured (i.e. manufactured physical objects, not necessarily owned by the organisation),

- intellectual (i.e. organizational, knowledge-based intangibles),

- human (i.e. peoples competencies, capabilities and experience, and their motivations to innovate),

- social and relationship (i.e. relationships within and between communities, groups of stakeholders and other networks and the ability to share information to enhance individual and collective well-being),

- natural (i.e. renewable and non-renewable environmental resources and processes that provide goods or services that support past, current or future prosperity of the company) (IIRC 2013b, 12-13).

It is claimed that $<\mathrm{IR}>$ enables a company to communicate in a clear, articulate way how it is drawing on different forms of "capitals" to create and preserve value across different time horizons.

\section{The company's Business Model}

The CD defines the business model as "an organization's chosen system of inputs, business activities, outputs and outcomes that aims to create value over the short, medium and long term" 
(IIRC 2013b, 36). As such it sets out strategic objectives and strategies to achieve them, which are implemented through resource allocation plans in a manner that considers both the maximization of opportunities and the mitigation or management of risks relevant to the company.

\section{Creation of value over time}

The CD suggests that the business model concept should be linked with the six capitals in order to demonstrate the extent to which companies create or destroy the resources or capitals as a result of their business activities. The Integrated Report will identify how the capitals are used, consumed or transformed by the company in producing outputs and whether or not they created or destroyed value.

\section{Guiding Principles}

The content and presentation of an Integrated Report is informed by the Guiding Principles. These include:

- Strategic focus and future orientation

- Connectivity of information

- Stakeholder responsiveness

- Materiality and conciseness

- Reliability and completeness

- Consistency and comparability

\section{Content Elements}

The CD requires that an Integrated Report should stand alone as a concise communication, linked to other reports and communications for those shareholders who want additional information (IIRC 2013b, 6). Seven Content Elements are identified as important in guiding preparation of the Integrated Report in a manner that provides each company's unique value creation story, including connections between the content elements. These Content Elements are provided as questions: 
- Organizational overview and external environment: "What does the company do and what are the circumstances under which it operates?"

- Governance: “How does the company's governance structure support its ability to create value in the short, medium and long term?"

- Opportunities and risks: "What are the specific opportunities and risks that affect the company's ability to create value over the short, medium and long term, and how is the company dealing with them?"

- Strategy and resource allocation: "Where does the company want to go and how does it intend to get there?"

- Business model: "What is the company's business model and to what extent is it resilient?"

- Performance: "To what extent has the company achieved its strategic objectives and what are its outcomes in terms of the capitals?"

- Future outlook: "What challenges and uncertainties is the company likely to encounter in pursuing its strategy, and what are the potential implications for its business model and future performance?" (IIRC 2013b, 7).

The IIRC suggest that the consideration of these principles will lead to specific benefits to the company. First, the company will have a more cohesive and efficient approach to its corporate reporting, thereby ensuring all factors that materially affect the ability of the organization to create value over time are included. Second, it will support integrated thinking and decision making in way that focuses on the creation of value over the short and long term. Benefits will also accrue to society via informed capital allocation as well as enhanced accountability and stewardship over the six capitals (IIRC 2013b, 8). Further, there is emerging evidence that companies providing Integrated Reports may enjoy a lower cost of capital similar to that noted by Dhaliwal et al. (2011) for companies providing sustainability reports (Integrated Reporting Council of South Africa (IRCSA 2011). 


\section{KEY ISSUES TO BE RESOLVED}

The issued included in this section are derived from the CD submission provided by an academic sub-committee of the IAAER. In providing these comments the sub-committee notes that their comments are supportive of the IIRC's objective to develop an international framework for Integrated Reporting $<\mathrm{IR}>$, and are delivered with the intent to enhance the acceptability of $<\mathrm{IR}>$ worldwide (please refer to the appendix for a complete list of comments, concerns and suggestions included in the CD submission by the sub-committee).

\section{Focus on providers of financial capital}

One of the key concerns noted in the submission was that the $<\mathrm{IR}>$ Framework identifies providers of financial capital as the primary users of an Integrated Report (IIRC 2013b, 8). While the CD states that the primary intended audience for an Integrated Report is "providers of financial capital", it does includes a clarification however it now also notes that "an integrated report and other communications resulting from $<\mathrm{IR}>$ will be of benefit to all stakeholders interested in an organization's ability to create value over time, including employees, customers, suppliers, business partners, local communities, legislators, regulators and policy-makers" (IIRC 2013b, 8). This clarification is likely a result of concerns noted in responses to the 2011 IIRC Discussion Paper (IIRC 2011), where many expressed the view that other stakeholders' needs were at least equally as important as investors'. The committee raised the concern that this clarification statement does not alleviate the potential for the focus on investors to be to the detriment of the information demands and needs of other key stakeholders (see Holder-Webb et al. 2009; Eccles, Cheng \& Saltzman 2010; Eccles \& Krzus 2010; KPMG 2011). 


\section{The meaning of "overall stock of capital" and trade-offs between capitals}

An important concept in chapter 2 of CD is the "overall stock of capitals"; however, this concept is currently not very well-defined. Paragraph 2.16 states that "...whether the net effect is an increase or decrease will depend on the perspective chosen", while paragraph 2.42 suggests that the aim of IR is not to "measure the value of an organization or all of the capitals". The combined effect is that the concepts of the stock and flow of capitals are very subjective, and that it will be difficult for organizations to explain some of their capitals beyond insubstantial narratives. For example, how does an organization go about assessing its stock of "shared norms, and common values and behaviors" (paragraph 2.17)? How can organizations meaningfully explain and evaluate the trade-

offs between capitals (e.g., environmental impacts versus profitability), without turning the disclosure into thinly veiled, self-promoting justifications? Also, unlike other forms of capitals, natural capitals do not "belong" to an organization; rather, the costs of a net decrease in natural capitals are likely borne by stakeholders other than investors (providers of financial capitals). To what extent is the discussion on such trade-offs meaningful to the primary audience of the integrated report?

\section{Assurance of integrated reports}

At the present stage of the development of $<\mathrm{IR}>$ a number of challenges exist for the assurance of Integrated Reports. In South Africa, where the majority of Integrated Reports are currently being produced, the assurance of Integrated Reports is currently limited to selected sustainability indicators, GRI application level checks, and occasionally the three Accountability principles. In certain instances reasonable assurance is being provided on the first two issues mentioned, but at present assurance providers have not yet been able to provide reasonable assurance on the Accountability principles. 
A number of major challenges stand in the way of reaching mature assurance practices in $<\mathrm{IR}>$. The following issues are not intended as a comprehensive list, but rather to highlight a number of highlevel challenges:

- Liability concerns of the major accounting firms (Eccles, 2012);

- No consensus around what a "true and fair" Integrated Report is (Eccles, 2012);

- Debates around whether the framework in its current form provides suitable criteria and appropriate subject matter to enable assurance of Integrated Reports, most notably a better understanding of, amongst others, the following concepts:

- Connectivity of reporting

- The impact of stakeholder responsiveness on reporting boundary

○ Completeness of the issues reported on.

- Concerns around whether the assurance of information contained in the Integrated Report can be conducted without assurance of the underlying processes as well.

In paragraph 5.21 of the $\mathrm{CD}$ it is stated that the "Framework provides reporting criteria against which organizations and assurance providers assess a report's adherence; it does not provide protocols for performing assurance engagements" (IIRC, 2013b).

The amount of professional judgment that currently underlies the preparation of Integrated Reports jeopardizes the criteria of neutrality. In the absence of consensus around the benchmarks that will provide broad guidance as to acceptable levels of interpretations of the $<\mathrm{IR}>$ principles, it is to be anticipated that assurance will trail reporting practice by a material amount of reporting cycles. The critical question that has to be asked in this regard is whether organizational stakeholders will express a sufficient amount of interest in Integrated Reports, in the absence of assurance, to ensure the survival of the $<\mathrm{IR}>$ movement over the short to medium term. 


\section{POTENTIAL FUTURE RESEARCH PROJECTS}

The development and introduction of $<\mathrm{IR}>$ presents many research opportunities using a variety of research methods. Due to the emerging nature of this form of reporting, little is known about how an Integrated Report will affect stakeholders or the companies preparing them. Typical research questions may include:

1. The decision relevance of the integrated report.

A key aim of $<\mathrm{IR}>$ is to communicate information about an organization's strategy, governance, performance and prospects. However, little is known about the extent to which potential users of an Integrated Report consider such information relevant.

- Does $<\mathrm{IR}>$ affect stakeholders' decisions?

- Does the form of the report affect stakeholder's decisions?

- Does the content of the report affect stakeholder's decisions?

- Which capitals do stakeholders value more?

2. $<\mathrm{IR}>$ and the capital market.

A driving force behind $<\mathrm{IR}>$ is the perceived inadequacy of financial information in informing the capital market about an organization's "true" value creation potential. A fruitful avenue of research is to examine whether and to what extent $<\mathrm{IR}>$ affects the capital market.

- $\quad$ Does $<\mathrm{IR}>$ affect cost of capital?

- Does $<\mathrm{IR}>$ affect analyst following or analyst accuracy?

- Does $<\mathrm{IR}>$ lead to success in attracting longer-term investors?

3. $<\mathrm{IR}>$ in practice.

A number of early adopters have started their $<\mathrm{IR}>$ journeys; as $<\mathrm{IR}>$ gains greater momentum, more research is needed to understand how $<\mathrm{IR}>$ is implemented, the challenges associated with practising $<\mathrm{IR}>$, and whether organizations achieve the intended benefits. . 
- What form should the Integrated Report take in order to present the interconnectedness between the financial and non-financial information?

- Is there a lack of connectivity between the different strains of reporting?

- How are organizations linking their core business activities to environmental, social or governance issues?

- How are companies developing and implementing their $<\mathrm{IR}>$ model?

- Are organizations succeeding in understanding their impact on all of the six capitals?

- Which performance metrics do companies report?

- Which performance metrics do stakeholders value?

- Does the implementation of $<\mathrm{IR}>$ result in changes to the business model?

- Does the implementation of $<\mathrm{IR}>$ result in integrated thinking?

- How do companies apply the Guiding Principles?

4. Is there a role for assurers in $<\mathrm{IR}>$ ? Do companies assure their Integrated Reports?

As $<\mathrm{IR}>$ develops, it will become increasingly important to ensure that Integrated Reports are considered to be credible by stakeholders. Research is needed to understand the value of assurance in increasing the credibility of Integrated Reports, as well as the impact assurance has on the decisions of stakeholders.

- What are the drivers for assurance of Integrated Reports?

- What impact does $<\mathrm{IR}>$ have on assurers' judgments?

- How do auditors apply the concepts of materiality and reliability?

- Does assurance of an $<\mathrm{IR}>$ impact on stakeholders decisions? 


\section{CONCLUSION}

The $<\mathrm{IR}>$ movement is in a critical phase of its development. The experience in South Africa has shown that the preparation of an Integrated Report is not overly complex. The more important question to be posed is whether $<\mathrm{IR}>$ changed the way organisations are doing business? In turn, does there need to be a change in the way the way that the providers of financial capital measure the performance of organisations? The link between the perceptions of the providers of financial capital regarding performance and the way in which executives have traditionally been remunerated is systemically intertwined. The ability of $<\mathrm{IR}>$ to play a role in accounting for value creation is not dependent on how effective organisations are in adopting the technical aspects of the CD, but rather on their ability to stimulate new thinking and action towards major business model adaptation.

To the extent that the providers of financial capital (and executives) remain too focused on shortterm financial performance will therefore hamper an organization's ability to implement the fundamental business model changes that are needed to provide the impetus towards accounting for value creation which is fundamental to $<\mathrm{IR}>$. 


\begin{tabular}{|c|c|c|}
\hline Question $^{1}$ & Concern/comments & Suggestions \\
\hline \multicolumn{3}{|l|}{ Chapter 1: Overview } \\
\hline \multirow[t]{2}{*}{$\begin{array}{l}\text { Principles-based } \\
\text { requirements } \\
\text { 1. Should any } \\
\text { additional principle- } \\
\text { based requirements be } \\
\text { added or should any } \\
\text { be eliminated or } \\
\text { changed? If so, please } \\
\text { explain why. }\end{array}$} & $\begin{array}{l}\text { The proposed framework takes the perspective of financial capital } \\
\text { providers. Given that integrated thinking is best served (for all } \\
\text { parties) when management answers to multiple stakeholders, } \\
\text { rather than a 'silo' focus on the shareholder perspective; and given } \\
\text { the extent that other capitals are deemed important enough to } \\
\text { include as inputs and outputs of the business model, both creating } \\
\text { value and somehow receiving value, the focus on financial capital } \\
\text { providers may reduce the impact of < }>\text { IR }>\text { as other stakeholder } \\
\text { perspectives and interests are not embedded (IAAER 2013). }\end{array}$ & $\begin{array}{l}\text { While taking the perspective of the financial capital } \\
\text { provider is inevitable in producing a workable } \\
\text { framework, this view may require further } \\
\text { justification and clarification. For example, it may } \\
\text { be useful to clarify that the <IR }>\text { framework is } \\
\text { intended to provide guidance for better external } \\
\text { reporting, rather than to prescribe the actual } \\
\text { processes behind the report. Although the } \\
\text { framework targets the financial capital provider as } \\
\text { the primary audience, it does not suggest that the } \\
\text { information gathering process should primarily } \\
\text { focus on the perspective of financial capital } \\
\text { providers" (IAAER 2013). }\end{array}$ \\
\hline & $\begin{array}{l}\text { The 'exclusion clauses' of 'unavailability of reliable data, specific } \\
\text { legal prohibitions or competitive harms', combined with the stated } \\
\text { key audience being the financial capital providers, can potentially } \\
\text { result in approved rationalization for organizations to avoid } \\
\text { disclosure of activities that are unfavourable to wider stakeholder } \\
\text { groups. For example, organizations may argue that certain trade- } \\
\text { off decisions between capitals (especially between non-financial } \\
\text { capitals, say, appeasing unions by keeping an operation in an } \\
\text { environmental sensitive area), may not require disclosure because } \\
\text { of its potential to reveal their strategic intent and hence cause } \\
\text { competitive harm. We note that 'strategic non-disclosure' may } \\
\text { not always be intentional; prior research has alerted us to the fact } \\
\text { that when managers are faced with difficult decisions, they will } \\
\text { both intentionally and subconsciously seek ways to justify a } \\
\text { course of action that is more desirable to themselves, especially if } \\
\text { there is an easy justification or if the negative effect is indirect } \\
\text { (e.g., Peters and Romi } 2013 \text { a, 2013b; Moore, Tanlu and Bazerman } \\
\text { 2010; Paharia, Kassam, Greene and Bazerman 2009; Festinger }\end{array}$ & $\begin{array}{l}\text { One way IIRC can help overcome this concern is to } \\
\text { provide additional guidance on what these three } \\
\text { exclusion clauses mean: "legal prohibitions" is clear } \\
\text { enough; but what is meant by "unavailability of } \\
\text { reliable data" - what is deemed reliable? Is the } \\
\text { concept consistent with the definition under IFRS? } \\
\text { What is meant by "competitive harm"? What are } \\
\text { examples of an acceptable "competitive harm" } \\
\text { argument? }\end{array}$ \\
\hline
\end{tabular}

\footnotetext{
${ }^{1}$ Comments in the submission are provided in the response format requested by the IIRC; i.e. as answers to a series of questions (as listed in the first column).
} 


\begin{tabular}{|c|c|c|}
\hline Question $^{1}$ & Concern/comments & Suggestions \\
\hline & $\begin{array}{l}\text { 1957). As managers are also known to focus more on short term } \\
\text { results even if they are aware of the need for long term-thinking } \\
\text { (e.g., Luft and Shields 2009; Farrell, Kadous and Towry 2008), } \\
\text { these three exclusion clauses in paragraphs 1.11-1.12 can } \\
\text { potentially facilitate undesirable non-disclosures. }\end{array}$ & \\
\hline $\begin{array}{l}\text { Integration with other } \\
\text { reports and } \\
\text { communications } \\
\text { 2. Do you agree with } \\
\text { how paragraphs } 1.18- \\
1.20 \text { characterize the } \\
\text { interaction with other } \\
\text { reports and } \\
\text { communications? }\end{array}$ & $\begin{array}{l}\text { Paragraph } 1.20 \text { suggests that one of the ways }<\mathrm{IR}>\text { builds on other } \\
\text { reporting is through the "combined emphasis on......and providers } \\
\text { of financial capital as the primary audience." [Italics added]. } \\
\text { Given many existing reporting frameworks focus on financial } \\
\text { capital providers, these italicised words do not assist in clearly } \\
\text { distinguishing the difference between }<\mathrm{IR}>\text { and other reports. }\end{array}$ & $\begin{array}{l}\text { There needs to be sufficient emphasis placed on the } \\
\text { fact that the integrated report is not intended to } \\
\text { replace other reports but instead it should "build on" } \\
\text { other reports. }\end{array}$ \\
\hline $\begin{array}{l}\text { 3. If the IIRC were to } \\
\text { create an online } \\
\text { database of } \\
\text { authoritative sources } \\
\text { of indicators or } \\
\text { measurement methods } \\
\text { developed by } \\
\text { established reporting } \\
\text { standard setters and } \\
\text { others, which } \\
\text { references should be } \\
\text { included? }\end{array}$ & $\begin{array}{l}\text { Given that each industry, and indeed each organization, has a } \\
\text { unique set of circumstances and strategy, it is not feasible to } \\
\text { provide definitive suggestions of indicators or measurement } \\
\text { methods. Indeed, it is often argued that indicators that uniquely } \\
\text { reflect an organization's operation and strategy are potentially } \\
\text { more informative than 'generic' indicators (e.g., Kaplan and } \\
\text { Norton 1996). Furthermore, there is a risk of giving legitimacy to } \\
\text { problematic indicators. }\end{array}$ & $\begin{array}{l}\text { It may be useful to encourage specific industries to } \\
\text { develop key performance areas of concern (rather } \\
\text { than key indicators) and benchmarking exercises to } \\
\text { aid their member organizations in their performance } \\
\text { measurement. It would also be useful to provide } \\
\text { guidance on desirable measurement attributes to } \\
\text { consider when choosing key performance } \\
\text { indicators. Expansion of the practical examples data } \\
\text { on the IIRC web site should also be encouraged. For } \\
\text { example, the SASB is developing industry norms in } \\
\text { relation to materiality. }\end{array}$ \\
\hline $\begin{array}{l}\text { Other } \\
\text { 4. Please provide any } \\
\text { other comments you } \\
\text { have about Chapter } 1 .\end{array}$ & & $\begin{array}{l}\text { In explaining the importance of value creation in the } \\
\text { short, medium and long term, it would be } \\
\text { worthwhile to re-emphasize that even though } \\
\text { financial capital holders are the key audience, } \\
\text { organizations are encouraged to discuss how value } \\
\text { is also created in other ways for other stakeholders. } \\
\text { For example, value can be created when other } \\
\text { capitals benefit (e.g. conservation), at the expense } \\
\text { of financial capitals. Firms should be encouraged to }\end{array}$ \\
\hline
\end{tabular}




\begin{tabular}{|c|c|c|}
\hline Question $^{1}$ & Concern/comments & Suggestions \\
\hline & & $\begin{array}{l}\text { disclose and explain how this type of value may } \\
\text { provide social returns for stakeholders. }\end{array}$ \\
\hline \multicolumn{3}{|c|}{ Chapter 2: Fundamental Concepts } \\
\hline $\begin{array}{l}\text { The capitals (Section } \\
\text { 2B) } \\
\text { 5. Do you agree with } \\
\text { this approach to the } \\
\text { capitals [The capitals } \\
\text { - Section 2B]? } \\
\text { Why/why not? }\end{array}$ & $\begin{array}{l}\text { Overall, the capitals approach to the framework provides a good } \\
\text { "completeness" check for the content of an integrated report. } \\
\text { Paragraph } 2.18 \text {, suggests that in some cases organizations' } \\
\text { interaction with some of the capitals may be "immaterial" for the } \\
\text { purpose of }<\mathrm{IR}>\text {. This paragraph introduces subjectivity and may } \\
\text { lead to an organization ignoring certain capitals. As will be } \\
\text { discussed further, the ambiguous concept of materiality } \\
\text { (especially when defined from the perspective of financial capital } \\
\text { providers) can result in inappropriate non-disclosure. }\end{array}$ & $\begin{array}{l}\text { An "apply or otherwise explain why not" approach } \\
\text { to the capitals would be beneficial in two ways: firs } \\
\text { it would force reporters to consider whether they } \\
\text { have addressed all of the capitals in their reports } \\
\text { and second, it will reduce discretion with respect to } \\
\text { "immaterial" items leading to non-disclosure. }\end{array}$ \\
\hline $\begin{array}{l}\text { 6. Please provide any } \\
\text { other comments you } \\
\text { have about Section } \\
\text { 2B? }\end{array}$ & $\begin{array}{l}\text { The requirement to explain trade-offs that influence value creation } \\
\text { over time, and the examples provided in paragraph } 2.25 \text { will be } \\
\text { beneficial in increasing the likelihood of long term thinking. It } \\
\text { also allows companies to justify difficult trade-offs. } \\
\text { With respect to } 2.16 \text {, further clarifications with regard to "overall } \\
\text { stock of capitals" would be helpful. Given that the target audience } \\
\text { of an integrated report is financial capital providers, and that } 2.16 \\
\text { acknowledges that "whether the net effect is an increase or } \\
\text { decrease will depend on the perspective taken", the combined } \\
\text { effect might be that "overall stock of capital" will primarily focus } \\
\text { on financial capital. For example, from the perspective of } \\
\text { financial capital providers, a trade-off between natural capital and } \\
\text { financial capital can easily be interpreted as an "overall increase in } \\
\text { capitals" if the positive impact on profit is significant. Further, } \\
\text { some of the capitals are more difficult to measure, making it easier } \\
\text { to justify an overall increase (e.g., it might be that only simple } \\
\text { narrative is sufficient to justify an increase in social and } \\
\text { relationship capital by referring to improved "shared norms, and } \\
\text { common values and behaviors"). Evidence of such behaviour can } \\
\text { be found in the accounting literature describing the self-serving } \\
\text { disclosure concerning legitimation tactics directed at aligning the } \\
\text { firm's norms and values with that of the larger society (e.g., } \\
\text { Patten, 1991, 1992, 1995, 2005; Cho and Patten 2007). }\end{array}$ & $\begin{array}{l}\text { To avoid self-serving disclosure (see also comments } \\
\text { to Question 1), further guidance on the concept of } \\
\text { "overall stock of capital" is important. }\end{array}$ \\
\hline
\end{tabular}




\begin{tabular}{|c|c|c|}
\hline Question $^{1}$ & Concern/comments & Suggestions \\
\hline & $\begin{array}{l}\text { With respect to paragraph } 2.22 \text {, the concepts of "availability" and } \\
\text { "affordability" require more clarification. Availability and } \\
\text { affordability appear to be similar concepts: if a capital is low in } \\
\text { availability, it is probably low in affordability, also. For example, } \\
\text { consider the natural capital of old growth forests. They are not } \\
\text { highly available (limited supplies), and therefore one would argue } \\
\text { that the providers of this capital (the eco-system) will consider this } \\
\text { resource not affordable. Unless you take the perspective of the } \\
\text { primary audience, the financial capital provider, who can } \\
\text { potentially consider this resource affordable if the organization } \\
\text { can find a low cost way of harvesting. }\end{array}$ & $\begin{array}{l}\text { One framework that has been used effectively for } \\
\text { intangible assets is Sveiby's (1997) framework on } \\
\text { intangible asset monitor. Sveiby suggests } \\
\text { identifying measures on (i) growth and renewal, (ii) } \\
\text { stability and (iii) efficiency. Applying these } \\
\text { concepts to the current context, three useful aspects } \\
\text { of measuring capitals might be growth (are there } \\
\text { any actions taken to grow this capital?), } \\
\text { availability/affordability, and quality (do these } \\
\text { capitals enable value creation?). }\end{array}$ \\
\hline 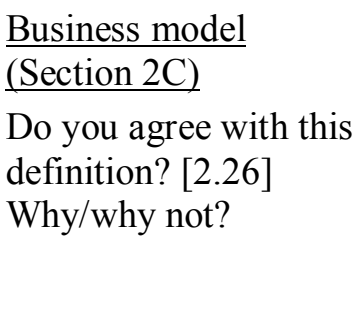 & Yes, this definition is reasonable. & $\begin{array}{l}\text { It might be helpful to also include a statement of } \\
\text { vision and value - the purpose of the organization. } \\
\text { A statement of vision and value helps investors } \\
\text { understand the rationale behind its subsequence } \\
\text { choices (e.g., the trade-offs of various capitals over } \\
\text { time). Disclosure of the reporting boundary may } \\
\text { also be appropriate. }\end{array}$ \\
\hline $\begin{array}{l}\text { 8. Do you agree with } \\
\text { this definition? [2.35- } \\
\text { 2.36] Why/why not? }\end{array}$ & $\begin{array}{l}\text { Yes, this definition is very inclusive, covering internal and } \\
\text { external, positive and negative consequences. The discussions in } \\
\text { paragraphs } 2.28 \text { (relating to how important it is to explain the } \\
\text { security, availability, quality and affordability of the components } \\
\text { of natural capital) and } 2.35 \text { (relating to the outcomes being } \\
\text { defined as the internal and external consequences - positive and } \\
\text { negative - for the capitals as a result of a firm's business activities } \\
\text { and outputs) are particularly useful. Further, including } \\
\text { externalities highlights the broader responsibilities of companies, } \\
\text { and is an improvement over the narrow focus in past reporting } \\
\text { frameworks. }\end{array}$ & \\
\hline $\begin{array}{l}\text { Other } \\
\text { 10. Please provide any } \\
\text { other comments you } \\
\text { have about Chapter } 2 \\
\text { that are not already } \\
\text { addressed by your }\end{array}$ & $\begin{array}{l}\text { Overall, we reiterate our concern that, because the integrated } \\
\text { report's primary audience is the financial capital providers, this } \\
\text { may lead organizations to continue to place greater burdens on } \\
\text { other stakeholders despite the claim in paragraph } 2.9 \text { that "the } \\
\text { organization and society therefore share both the cost of the } \\
\text { capital used as inputs and the value created by the organization." }\end{array}$ & \\
\hline
\end{tabular}




\begin{tabular}{|c|c|c|}
\hline Question $^{1}$ & Concern/comments & Suggestions \\
\hline responses above. & $\begin{array}{l}\text { That is, oftentimes the cost of capital comes mainly from society } \\
\text { but the value created is mostly restricted to financial capital } \\
\text { providers. } \\
\text { With respect to paragraph 2.39, it is not clear how <IR }>\text { supports } \\
\text { "broader societal interests by encouraging the allocation of } \\
\text { financial capital to reward and support long term, as well as the } \\
\text { short and medium term, value creation within planetary limits and } \\
\text { societal expectations". This statement needs greater clarification. } \\
\text { There is no clear provision to say that value is being created } \\
\text { within any limits, unless management decides those "limits" are } \\
\text { material, in an important capital that they choose to report on, and } \\
\text { are willing to discuss negatives or risks associated with such } \\
\text { limits. } \\
\text { With respect to paragraph 2.40, although it indicates that <IR }>\text { is } \\
\text { based on an understanding that future cash flows are dependent on } \\
\text { a wider range of capitals, firms are not, at any point, asked to be } \\
\text { truly accountable to those capitals. } \\
\text { Accounting research indicates users are not able to garner a true } \\
\text { assessment of non-financial performance based on firm } \\
\text { disclosures, which raises the question, what really is <IR> } \\
\text { offering in the way of additional information to report (e.g. Gray } \\
\text { et al., 1995; Guthrie and Parker, 1989; Cho and Patten, 2007; } \\
\text { Patten, 1991, 1992, 1995, 2005; Walden and Schwartz, 1997; } \\
\text { Brown and Deegan, 1998; O'Donovan, 2002; Deegan et al., 2002; } \\
\text { Bansal and Clelland, 2004) }\end{array}$ & $\begin{array}{l}\text { Perhaps there is a need to improve clarity around } \\
\text { these issues by tying the discussion back to the } \\
\text { concepts of availability and affordability. }\end{array}$ \\
\hline \multicolumn{3}{|c|}{ Chapter 3: Guiding principles } \\
\hline $\begin{array}{l}\text { Materiality and } \\
\text { conciseness (Section } \\
\text { 11. Do you agree with } \\
\text { this approach to } \\
\text { materiality? If not, } \\
\text { how would you } \\
\text { change it? }\end{array}$ & $\begin{array}{l}\text { The definition of materiality presented in paragraph } 3.23 \text { rests on } \\
\text { an item being able to "substantively influence" the "primary } \\
\text { intended report users", (which the first sections of the framework } \\
\text { identify to be those supplying financial capital). We identify three } \\
\text { concerns with this approach. } \\
\text { First, materiality should not be limited to financial capitals else } \\
\text { the reporting will be skewed to items creating a financial } \\
\text { return/impact on the financial capital. Materiality depends on both } \\
\text { quantitative and qualitative factors: a matter may be material due }\end{array}$ & $\begin{array}{l}\text { During the integrated reporting process, the } \\
\text { materiality of an item should be considered purely } \\
\text { on its relevance to affect the organizations ability to } \\
\text { create value in the short, medium and long term. At }\end{array}$ \\
\hline
\end{tabular}




\begin{tabular}{|c|c|c|}
\hline Question $^{1}$ & Concern/comments & Suggestions \\
\hline & $\begin{array}{l}\text { to its nature or its size. } \\
\text { Second, this is a report-driven rather reporting process materiality } \\
\text { approach. In fact the framework does not address materiality in } \\
\text { terms of the process of creating the report, but only in terms of the } \\
\text { report itself. Even if the issues that the organization chooses to } \\
\text { report are those that are material to investors, this should not mean } \\
\text { that the underlying reporting processes should be unduly skewed } \\
\text { to favor investors, since this would not be in the best interest of } \\
\text { the organizations ability to create value in the short medium and } \\
\text { longer term. Please also see comments to Question } 1 . \\
\text { Finally, although paragraph } 3.26 \text { notes a firm should include } \\
\text { negative matters voluntarily in this report, accounting research has } \\
\text { shown that firms will disregard reporting requirements if they feel } \\
\text { the information may harm stock prices, thus they may be less } \\
\text { inclined to follow such a mandate (Peters and Romi 2013a). } \\
\text { Further, the audit function also does not fully support the } \\
\text { completeness assertion of the disclosures. } \\
\text { It is stated that materiality depends on both relevance and } \\
\text { importance; and importance in turn refers to the nature and } \\
\text { magnitude of the matter (see footnote } 5 \text { on p.21 of the } \\
\text { Consultative Draft). However, in 5B, importance is more } \\
\text { explicitly defined as a combination of the magnitude and } \\
\text { likelihood (not nature) of the matter. This could potentially create } \\
\text { some confusion. Further, it is not clear from the guidelines how } \\
\text { one can assess the magnitude/nature of matters, especially in } \\
\text { relation to social matters. }\end{array}$ & $\begin{array}{l}\text { this point the source of the item is not relevant, it } \\
\text { can come from any stakeholder group; the } \\
\text { individual circumstances of the entity will dictate } \\
\text { what is relevant in terms of the value creations } \\
\text { process. } \\
\text { It is recognized that it would be impossible to cater } \\
\text { to the perspectives of all stakeholders, thus one } \\
\text { group of intended users will take precedence. That } \\
\text { said, if the intended users are short term investors, } \\
\text { then changes to some of the capitals may not be } \\
\text { seen as material. Thus we suggest that an additional } \\
\text { clause be added to read: "substantively affect the } \\
\text { assessment of a provider of capital of their intention } \\
\text { to continue to provide capital to the company." } \\
\text { It will be useful for the }<\text { IR }>\text { Framework to provide } \\
\text { guidance on the social indicators of importance (e.g. } \\
\text { GRI guidelines and ISO26000). Either best practice } \\
\text { consensus within industries may assist in this } \\
\text { process, or a number of exemplar KPIs (KRIs) } \\
\text { which combine quantitative information with } \\
\text { qualitative information could be provided by the } \\
\text { <IR }>\text { Framework. This will allow comparison of } \\
\text { KPIs that are consistent over time and in a way that } \\
\text { enables comparison with other organizations to the } \\
\text { extent it is material to the organization's own value } \\
\text { creation story. }\end{array}$ \\
\hline $\begin{array}{l}\text { Please provide any } \\
\text { other comments you } \\
\text { have about Section 3D } \\
\text { or the Materiality } \\
\text { determination process } \\
\text { (Section 5B). }\end{array}$ & $\begin{array}{l}\text { Paragraph } 3.27 \text { suggests that materiality assessment is to be } \\
\text { integrated to "everyday management". This seems to suggest a } \\
\text { need for continuous assessments which may be perceived as quite } \\
\text { a burden. }\end{array}$ & $\begin{array}{l}\text { The guidelines provided by GRI and ISO } 26000 \text { may } \\
\text { assist in prioritizing social indicators that may be } \\
\text { considered material. }\end{array}$ \\
\hline $\begin{array}{l}\text { Reliability and } \\
\text { completeness (Section } \\
\underline{\text { 3E) }}\end{array}$ & $\begin{array}{l}\text { A highly reliable integrated reporting process involves a circular } \\
\text { process: the indicators that the organization uses to measure its } \\
\text { strategic performance are subject to a robust materiality }\end{array}$ & $\begin{array}{l}\text { The IASB and the FASB consider relevance to be } \\
\text { more important than reliability, suggesting that } \\
\text { reliability may not be the most critical consideration }\end{array}$ \\
\hline
\end{tabular}




\begin{tabular}{|c|c|c|}
\hline Question $^{1}$ & Concern/comments & Suggestions \\
\hline $\begin{array}{l}\text { 13. How should the } \\
\text { reliability of an } \\
\text { integrated report be } \\
\text { demonstrated? }\end{array}$ & $\begin{array}{l}\text { determination process; the information that is fed into the } \\
\text { materiality determination process is subject to a robust stakeholder } \\
\text { engagement process; and a robust stakeholder engagement process } \\
\text { would be subject to a comprehensive understanding of the entities } \\
\text { business model and its value chain, as well as the internal and } \\
\text { external operating environment. The connectivity of these } \\
\text { different elements of the integrated reporting process is thus } \\
\text { compulsory to gauge reliability. The factual correctness of any } \\
\text { piece of information in the integrated report is subject to the } \\
\text { connectivity principle; otherwise the relevance thereof cannot be } \\
\text { illustrated. } \\
\text { Completeness is not addressed within this question, but remains a } \\
\text { key element of report reliability. } \\
\text { Paragraph } 5.21 \text { mentions that "the framework provides reporting } \\
\text { criteria against which organizations and assurance providers } \\
\text { assess a reports adherence". } \\
\text { This creates the impression that the framework will yield } \\
\text { appropriate subject matter that can be subjected to criteria from } \\
\text { assurance providers, however the framework is silent on what } \\
\text { appropriate subject matter will look like. Industry norms and best } \\
\text { practice are still being developed. It is thus a challenge to } \\
\text { understand exactly what appropriate subject matter will look like. }\end{array}$ & $\begin{array}{l}\text { The value of assurance and the nature of appropriate } \\
\text { subject matter that is suitable for assurance could be } \\
\text { further addressed in the framework. Report } \\
\text { preparers should be encouraged to prepare reports } \\
\text { as though it will be subject to external assurance. } \\
\text { This will mean that an audit trail should be } \\
\text { maintained for information that is being presented } \\
\text { in the integrated report as far as possible. More } \\
\text { importantly, where reporting organizations } \\
\text { endeavor to develop disclosures that are not covered } \\
\text { within an existing industry framework, the } \\
\text { management assumptions that underlie these } \\
\text { disclosures should be developed with an } \\
\text { understanding of what appropriate subject matter } \\
\text { looks like. Should this subject matter then be } \\
\text { subject to assurance, the management assumptions } \\
\text { will assist assurance providers to develop suitable } \\
\text { criteria to assure these disclosures. It will thus } \\
\text { greatly assist reporting organizations to understand } \\
\text { what appropriate subject matter looks like, and what }\end{array}$ \\
\hline
\end{tabular}




\begin{tabular}{|c|c|c|}
\hline Question $^{1}$ & Concern/comments & Suggestions \\
\hline & & the attributes of suitable criteria looks like. \\
\hline $\begin{array}{l}\text { 14. Please provide any } \\
\text { other comments you } \\
\text { have about Section } \\
3 \mathrm{E} \text {. }\end{array}$ & $\begin{array}{l}\text { No guidance is provided to assist in assessing what an acceptably } \\
\text { low level of freedom from material bias would be. }\end{array}$ & \\
\hline $\begin{array}{l}\text { Other } \\
15 . \text { Please provide } \\
\text { any other comments } \\
\text { you have about } \\
\text { Chapter } 3 \text { that are not } \\
\text { already addressed by } \\
\text { your responses above }\end{array}$ & $\begin{array}{l}\text { The discussion in paragraph } 3.16 \text { relating to the need to } \\
\text { understand, incorporate, and respond to key stakeholders } \\
\text { legitimate needs, interests and expectations is useful. } \\
\text { To the extent the framework is applied, at a minimum, }<\mathrm{IR}>\text { will } \\
\text { centralize information firms already report/misreport in a } \\
\text { disaggregated fashion, however the extent to which < }<\mathrm{IR}> \\
\text { enhances transparency and accountability will be a function of } \\
\text { management integrity. }\end{array}$ & \\
\hline \multicolumn{3}{|c|}{ Chapter 5: Preparation and presentation } \\
\hline $\begin{array}{l}\text { Involvement of those } \\
\text { charged with } \\
\text { governance (Section } \\
\text { 5D) } \\
\text { 17. Should there be a } \\
\text { requirement for those } \\
\text { charged with } \\
\text { governance to include } \\
\text { a statement } \\
\text { acknowledging their } \\
\text { responsibility for the } \\
\text { integrated report? } \\
\text { Why/why not? }\end{array}$ & $\begin{array}{l}\text { The experience in South Africa suggests that without high-level } \\
\text { buy-in integrated reporting can become a somewhat academic } \\
\text { exercise (Deloitte 2012). }\end{array}$ & $\begin{array}{l}\text { Buy-in may be enhanced by an alignment between } \\
\text { executive remuneration and strategic objectives } \\
\text { outlined in the }<\mathrm{IR}>\text { framework. } \\
\text { Consider a requirement to include an } \\
\text { acknowledgement that the processes employed in } \\
\text { preparing the integrated report are reasonable, rather } \\
\text { than focus only on the outcomes. In addition, since } \\
\text { an internal audit may enhance/be perceived to } \\
\text { enhance the integrated report reliability this process } \\
\text { should also be disclosed. }\end{array}$ \\
\hline $\begin{array}{l}\text { 18. Please provide any } \\
\text { other comments you } \\
\text { have about } \\
\text { involvement of those } \\
\text { charged with } \\
\text { governance (Section } \\
\text { 5D). }\end{array}$ & $\begin{array}{l}\text { Research indicates that firm's with governance bodies assigned to } \\
\text { particular reporting subjects (e.g. environmental) do render greater } \\
\text { reporting quality about that information (Peters and Romi 2013b). }\end{array}$ & \\
\hline
\end{tabular}




\begin{tabular}{|c|c|c|}
\hline Question $^{1}$ & Concern/comments & Suggestions \\
\hline $\begin{array}{l}\text { Credibility (Section } \\
\underline{5 \mathrm{E})} \\
19 . \text { If assurance is to } \\
\text { be obtained, should it } \\
\text { cover the integrated } \\
\text { report as a whole, or } \\
\text { specific aspects of the } \\
\text { report? Why? }\end{array}$ & $\begin{array}{l}\text { Due to the amount of discretion allowed in this reporting } \\
\text { framework we believe that external and independent assurance } \\
\text { should be required to provide credibility to the integrated report. } \\
\text { This assurance should extend to the entire report given that whole } \\
<\mathrm{IR}>\text { concept is about connectivity. Also, report users may not } \\
\text { distinguish between the information that is assured and the } \\
\text { information that is not assured. It may be that investors will } \\
\text { assume the whole report is already verified even if only one part } \\
\text { is. It will also be difficult to assure the integrated report without } \\
\text { assuring the underlying process. } \\
\text { The level of assurance is debatable. An alternative would be } \\
\text { independent assurance of process compliance - i.e. that the } \\
\text { company has a system in place that can ensure integrity (e.g. ISO } \\
9000 \text { ) }\end{array}$ & \\
\hline $\begin{array}{l}\text { Other } \\
\text { 21. Please provide any } \\
\text { other comments you } \\
\text { have about Chapter } 5 \\
\text { that are not already } \\
\text { addressed by your } \\
\text { responses above } \\
\text { (please include } \\
\text { comments on the } \\
\text { materiality } \\
\text { determination process } \\
\text { [Section } 5 \mathrm{~B} \text { ] in your } \\
\text { answer to question } 11 \\
\text { above rather than } \\
\text { here). }\end{array}$ & & $\begin{array}{l}\text { In assessing importance, it may be beneficial to } \\
\text { comment on the need to consider the company's } \\
\text { risk appetite (i.e. its willingness to tolerate risks in } \\
\text { pursuit of returns). } \\
\text { Also, the materiality assessment is geared towards } \\
\text { future events (past and current events have } 100 \% \\
\text { likelihood of occurrence since they have already } \\
\text { occurred). Perhaps other dimensions can be } \\
\text { discussed; e.g., current impact vs. length of impact } \\
\text { (if current impact is small but it will have long term } \\
\text { implications it may still be important; if high on } \\
\text { both dimensions it is definitely important; if low on } \\
\text { both dimensions it is not important). }\end{array}$ \\
\hline $\begin{array}{l}\text { Overall view } \\
22 . \text { Recognizing that } \\
<\text { IR }>\text { will evolve over } \\
\text { time, please explain } \\
\text { the extent to which } \\
\text { you believe the }\end{array}$ & $\begin{array}{l}\text { The overall approach to reporting is appropriate. The inclusion of } \\
\text { capitals, the discussion of risks and opportunities associated with } \\
\text { short, medium and long-term success, etc. are all commendable } \\
\text { reporting practices. }\end{array}$ & $\begin{array}{l}\text { The shortcoming of the }\langle\mathrm{IR}>\text { framework is found in } \\
\text { the principles-based approach that allows } \\
\text { management significant discretion in reporting. } \\
\text { More rules and specific requirements and examples } \\
\text { would be a better approach in the initial stages of } \\
\text { this reporting framework development. It is hoped }\end{array}$ \\
\hline
\end{tabular}




\begin{tabular}{|c|c|c|}
\hline Question $^{1}$ & Concern/comments & Suggestions \\
\hline $\begin{array}{l}\text { content of the } \\
\text { Framework overall is } \\
\text { appropriate for use by } \\
\text { organizations in } \\
\text { preparing an } \\
\text { integrated report and } \\
\text { for providing report } \\
\text { users with information } \\
\text { about an } \\
\text { organization's ability } \\
\text { to create value in the } \\
\text { short, medium and } \\
\text { long term? }\end{array}$ & & $\begin{array}{l}\text { that over time, as indicators, measurements, and } \\
\text { societal expectations evolve, the reporting practices } \\
\text { will follow. } \\
\text { Without clear guidelines and top executive buy-in, } \\
\text { there is a risk that this framework will not provide } \\
\text { any information to users about an organization's } \\
\text { ability to create value in any term, beyond what is } \\
\text { already available. This belief is not because the } \\
\text { information requested is not valuable, it is based on } \\
\text { the belief that organizations will not provide the } \\
\text { information as requested. } \\
\text { Paragraph } 1.8 \text { suggests that long term investors' } \\
\text { interests are aligned with other stakeholders as long } \\
\text { term investors want long term value creation. This } \\
\text { view can potentially be challenged by considering } \\
\text { recent worldwide financial events and crises. }\end{array}$ \\
\hline $\begin{array}{l}\text { Development of }<\mathrm{IR}> \\
\text { 23. If the IIRC were to } \\
\text { develop explanatory } \\
\text { material on }<\mathrm{IR}>\text { in } \\
\text { addition to the } \\
\text { Framework, which } \\
\text { three topics would you } \\
\text { recommend be given } \\
\text { priority? Why? }\end{array}$ & $\begin{array}{l}\text { The audience; the capital inclusions; and materiality. } \\
\text { The audience: Per previous discussions, the primary audience } \\
\text { being financial capital providers limits a firm's accountability, } \\
\text { limits a firm's vantage point on what creates or destroys value, } \\
\text { and does not render anything beyond what we presently have in } \\
\text { public financial reports. } \\
\text { The capitals: All firms should have to include information for all } \\
\text { capitals. It is true that some will be more important for some firms } \\
\text { than others, but firms should have to disclose why they are not } \\
\text { considering a specific capital in relation to inputs, operations, and } \\
\text { outputs. } \\
\text { The materiality: The materiality section needs improvement. } \\
\text { Materiality has traditionally been based on inclusion of } \\
\text { information that may make a difference in the decisions made by } \\
\text { users, and we still see management continuously (and predictably } \\
\text { for negative information) not include items based on self-serving } \\
\text { motives. The definition of materiality should consider ways of } \\
\text { reflecting management's motivation to withhold harmful, but } \\
\text { indeed important information. }\end{array}$ & \\
\hline
\end{tabular}




\begin{tabular}{|l|l|l|}
\hline Question $^{1}$ & Concern/comments & Suggestions \\
\hline Other & About forty listed Japanese companies have already prepared & \\
24. Please provide any & integrated reports. Many companies state that integrated reporting \\
other comments not & will enhance corporate management through (1) better managerial \\
already addressed by & training, (2) better risk management, and (3) improved \\
your responses to & accountability of management, investor protection and the \\
Questions 1-23. & meaningfulness of financial statements. & \\
\hline
\end{tabular}




\section{REFERENCES}

Adams, S., J. Fries, and R. Simnett. 2011. The journey toward Integrated Reporting. Accountants Digest 558: 1-41.

Bansal, P., and Clelland, I. 2004. Talking Trash: Legitimacy, impression management, and unsystematic risk in the context of the natural environment. Academy of Management Journal, 47(1), $93-103$.

Brown, N., and Deegan, C. 1998. The public disclosure of environmental performance information - a dual test of media agenda setting theory and legitimacy theory. Accounting and Business Research, 29(1), $21-42$.

Cho, C. H. and Patten, D. M. 2007. The role of environmental disclosures as a tool of legitimacy: A research note. Accounting, Organizations and Society, 32, $639-647$.

Clarkson, P., Y. Li. and G. Richardson. 2004. The market valuation of environmental expenditures by pulp and paper companies. The Accounting Review 70: 329-353.

Cohen, J., L. L. Holder-Webb, L. Nath, and D. Wood. 2012. Corporate reporting on nonfinancial leading indicators of economic performance and sustainability. Accounting Horizons 26 (1): 65-90.

Deegan, C., and Gordon, B. 1996. A study of environmental disclosure practices of Australian corporations. Accounting and Business Research, 26(3), 187 - 199.

Deegan, C. and Rankin, M. 1996. Do Australian companies report environmental news objectively? An analysis of environmental disclosures by firms prosecuted successfully by the Environmental Protection Authority. Accounting, Auditing and Accountability Journal, 2, 50 67.

Deegan C., Rankin, M., and Tobin, J. 2002. An examination of the corporate social and environmental disclosures of GHP from 1983-1997: A test of legitimacy theory. Accounting, Auditing and Accountability Journal, 15(3), 312 - 343.

Deloitte. 2012. Integrated Reporting: Navigating Your Way to a Truly Integrated Report.

Dhaliwal, D., L. Zhen, A. Tsang, \& Y. George. 2011. Voluntary non-financial disclosure and the cost of equity capital: The initiation of corporate social responsibility reporting. The Accounting Review 86 (1): 59-100.

Dhaliwal, D., S. Radhakrishnan, A. Tsang \& Y. G. Yang. 2012. Non-financial disclosure and analyst forecast accuracy: International evidence on corporate social responsibility disclosure. The Accounting Review 87 (3): 723-760.

Eccles, R., B. Cheng, and D. Saltzman (eds). 2010. The Landscape of Integrated Reporting. Boston: Harvard Business School (Ebook). 
Eccles, R., and M. Krzus. 2010. One Report: Integrated Reporting for a Sustainable Strategy. United States of America: John Wiley \& Sons.

Eccles, R., M.P. Krzus, and L.A. Watson, 2012. Integrated Reporting Requires Integrated Assurance, in Oringel, J. (Ed.) Effective Auditing for Corporates: Key Developments in Practice and Procedures, Bloomsbury Information, London, UK: $161-178$.

Ernst \& Young. 2012. Sustainability Reporting gets a Boost from Stock Exchanges. Available at: http://www.ey.com/Publication/vwLUAssets/Stock_exchanges_and_sustainability_reporting/\$ FILE/Stock_exchanges_and_sustainability_reporting.pdf.

Farrell, A., K. Kadous, and K. Towry. 2008. Contracting on contemporaneous versus forwardlooking measures: an experimental investigation. Contemporary Accounting Research. 25(3): 773-802

Festinger, L., 1957, A Theory of Cognitive Dissonance (Stanford University Press, Palo Alto, CA). Financial Reporting Council (FRC). 2009. Louder than Words: Principles and Actions for Making Corporate Reports Less Complex and More Relevant. Available at: http://frc.org.uk/getattachment/7d952925-74ea-4deb-b659-e9242b09f2fa/Louder-thanwords.aspx.

Financial Reporting Council (FRC). 2011. Cutting clutter. Combating clutter in annual reports. Available at: http://www.frc.org.uk/Our-Work/Publications/FRC-Board/Cutting-ClutterCombating-clutter-in-annual-report.aspx.

Guthrie, J., and Parker, L. 1989. Corporate social reporting: A rebuttal of legitimacy theory. Accounting and Business Research, 9(76), 343 - 352.

Holder-Webb, L., J. Cohen, L. Nath, and D. Wood. 2008. A survey of governance disclosures among U.S. firms. Journal of Business Ethics (December): 543-563.

Holder-Webb, L., J. Cohen, L. Nath, and D. Wood. 2009. The supply of corporate social responsibility disclosure among U.S. firms. Journal of Business Ethics (February): 497-527.

International Association for Accounting Education and Research (IAAER) 2013. Response to Consultation Draft of the International $<\mathrm{IR}>$ Framework. Available at: http://www.theiirc.org/consultationdraft2013/

International Integrated Reporting Council (IIRC). 2011. Discussion Paper: Towards Integrated Reporting - Communicating Value in the 21st Century. Available at: http://theiirc.org/wpcontent/uploads/2011/09/IR-Discussion-Paper-2011_spreads.pdf.

International Integrated Reporting Council (IIRC). 2012b. The Pilot Program 2012 Yearbook: Capturing the Experiences of Global Businesses and Investors. Available at: http://theiirc.org/wp-content/uploads/2011/09/IR-Discussion-Paper-2011_spreads.pdf. 
International Integrated Reporting Council (IIRC). 2013a. Integrated reporting: The IIRC. Available at: http://www.theiirc.org/.

International Integrated Reporting Council (IIRC). 2013b. Consultation Draft of the International $<I R>$ Framework. Available at: http://www.theiirc.org/wp-content/uploads/ConsultationDraft/Consultation-Draft-of-the-InternationalIRFramework.pdf.

International Integrated Reporting Council (IIRC). 2013c. European Commission proposals: An important milestone on the journey towards Integrated Reporting. Available at:

http://www.theiirc.org/2013/04/30/european-commission-proposals-an-important-mileston-onthe-journey-towards-integrated-reporting/.

International Reporting Committee of South Africa (IRCSA). 2011. Framework for Integrated Reporting and the Integrated Report: Discussion paper. Available at: http://www.sustainabilitysa.org/Portals/0/IRC\%20of\%20SA\%20Integrated\%20Reporting\%20 Guide\%20Jan\%2011.pdf.

Investor Responsibility Research Centre Institute (IRRCI). 2013. Integrated Financial and Sustainability Reporting in the United States. Available at: http://irrcinstitute.org/pdf/FINAL_Integrated_Financial_Sustain_Reporting_April_2013.pdf.

Kaplan, R. S., and D. P. Norton. 1996. The Balanced Scorecard: Translating Strategy into Action. Boston, MA: Harvard Business School Press.

KPMG. 2011. International survey of corporate responsibility reporting. Available at: http://www.kpmg.com/au/en/issuesandinsights/articlespublications/pages/kpmg-internationalsurvey-corporate-responsibility-reporting-2011.aspx.

KPMG and Financial Executives Research Foundation (FERF). 2011. Disclosure Overload and Complexity: Hidden in Plain Sight. Available at: http://www.kpmg.com/US/en/IssuesAndInsights/ArticlesPublications/Documents/disclosureoverload-complexity.pdf.

Luft, J., and M. Shields. 2009. Psychology models of management accounting. Foundations and Trends in Accounting. 4 (3/4): 199-345

Milne, M. J., and Patten, D. M. 2002. Securing organizational legitimacy: An experimental decision case examining the impact of environmental disclosures. Accounting, Auditing and Accountability Journal, 15(3), 372 - 405.

Moore, D. A., L. Tanlu, M. Bazerman. 2010. Conflict of interest and the intrusion of bias. Judgment and Decision Making. 5(1): 37-53

O’Donovan, G. 2002. Environmental disclosures in the annual report: Extending the applicability and predictive power of legitimacy theory. Accounting, Auditing and Accountability Journal, 15(3), $344-371$. 
Paharia, N., K. S. Kassam, J. D. Greene, and M. H. Bazerman. 2009. Dirty work, clean hands: The moral psychology of indirect agency. Organizational Behavior and Human Decision Processes. 109: 134-141

Patten, D. M. 1991. Exposure, legitimacy, and social disclosure. Journal of Accounting and Public Policy, 10, $297-308$.

Patten, D. M. 1992. Intra-industry environmental disclosures in response to the Alaskan Oil Spill: A note on legitimacy theory. Accounting, Organization and Society, 17(5), 471 - 475.

Patten, D. M. 1995. Variability in social disclosure: A legitimacy-based analysis. Advances in Public Interest Accounting, 6, 273 - 285.

Patten, D. M. 2005. The accuracy of financial report projections of future environmental capital expenditures: A research note. Accounting, Organizations and Society, 30, 457 - 468.

Peters, G.F. and Romi, A.M. 2013a. Discretionary compliance with mandatory environmental disclosures: Evidence from SEC filings. Journal of Accounting and Public Policy 32: 213-236.

Peters, G.F, and Romi, A.M. 2013b. Does the voluntary adoption of corporate governance mechanisms improve environmental risk disclosures? Evidence from greenhouse gas emission accounting. Working Paper, Texas Tech University.

Simnett, R., A. Vanstraelen, \& W. F. Chua. 2009a. Assurance on sustainability reports: An international comparison. The Accounting Review 84 (3): 937-968.

Sveiby, K. E. 1997. The New Organizational Wealth. Berett-Koehler Publishers, Inc. San Francisco.

Walden, W. D., and Schwartz, B. N. 1997. Environmental disclosures and public policy pressure. Journal of Accounting and Public Policy, 16, 125 - 154. 